\title{
ANALISIS KEPUASAN WISATAWAN NUSANTARA BERBELANJA DI KRISNA OLEH-OLEH KHAS BALI
}

\author{
Yosia Nanda Anggriawan ${ }^{1}$, NMS. Wijaya ${ }^{2}$, LGLK. Dewi ${ }^{3}$ \\ ${ }^{1}$ Email: yosiayosnanda@gmail.com \\ Program Studi Industri Perjalanan Wisata, Fakultas Pariwisata, Universitas Udayana \\ 2Email: sofia_ipw@unud.ac.id \\ Program Studi Industri Perjalanan Wisata, Fakultas Pariwisata, Universitas Udayana \\ ${ }^{3}$ Email: leli_ipw@unud.ac.id \\ Program Studi Industri Perjalanan Wisata, Fakultas Pariwisata, Unuiversitas Udayana
}

\begin{abstract}
The purpose of this study was to find out the satisfaction of shopping for domestic tourist at Krisna Oleh-Oleh Khas Bali. Based on statistical data, domestic tourists who choose shopping tourism activities and allocation of expenditure to buy souvenirs while on vacation to Bali ranks in the second place. Data were collected by observation, questionnaire, documentation, and literature study using accidental \& purposive sampling techniques with a total of 100 respondents. To analyze data, the data analysis techniques used are validity, reliability, expectation and satisfaction. Measurements are made with three factors that influence the satisfaction of the tourist shopping of the domestic tourist in Krisna Oleh-Oleh Khas Bali. The three factors are in-store, out-store, and marketing mix and the average value of expectation is 4.14 which is in the important category, then the average value of the performance level of 3.81 is in the good category. From the results of the level of expectation and level of performance, the suitability level of $92.4 \%$ is categorized as less satisfied, which means that the domestic tourists who shop at Krisna Oleh-Oleh Khas Bali feel less satisfied. There are 7 indicators that are a priority in Krisna Oleh-Oleh Khas Bali to be improved, the indicators are the instore scent, food court cleanliness, food court comfort, waiting area comfort, noise levels, special offers or discounts, and prices. The advice that can be given to Krisna Oleh-Oleh Khas Bali is to improve the performance that is deemed lacking like the priority already mentioned.
\end{abstract}

\begin{abstract}
Abstrak : Tujuan penelitian ini adalah untuk mengetahui kepuasan berbelanja wisatawan nusantara di Krisna Oleh-Oleh Khas Bali. Berdasarkan data statistik, wisatawan nusantara yang memilih kegiatan wisata belanja dan alokasi pengeluaran untuk membeli souvenir saat belibur ke Bali menempati peringkat kedua terbanyak. Data dikumpulkan dengan cara observasi, kuesioner, dokumentasi, dan studi kepustakaan menggunakan teknik accidental \& purposive sampling dengan jumlah sebanyak 100 responden. Untuk menganalisis data, teknik analisis data yang digunakan adalah uji validitas, uji reliabilitas, analisis harapan dan tingkat kepuasan. Pengukuran dilakukan dengan tiga faktor yang mempengaruhi kepuasan berbelanja wisatawan nusantara di Krisna Oleh-Oleh Khas Bali Kawasan Bali. Tiga faktor tersebut adalah in-store, out-store, dan marketing mix dan didapatkan nilai rata-rata tingkat harapan sebesar 4,14 yang masuk kategori penting, kemudian nilai rata-rata tingkat kinerja sebesar 3,81 yang masuk kategori baik. Dari hasil tingkat harapan dan tingkat kinerja didapatkan tingkat kesesuaian sebesar 92,4\% yang masuk kategori kurang puas yang artinya wisatawan nusantara yang berbelanja di Krisna Oleh-Oleh Khas Bali merasa kurang puas. Terdapat 7 indikator yang menjadi prioritas di Krisna Oleh-Oleh Khas Bali untuk ditingkatkan, indikator tersebut adalah aroma didalam toko, kebersihan food court, kenyamanan food court, kenyamanan area tunggu, tingkat kebisingan, penawaran spesial atau diskon, dan harga. Saran yang bisa diberikan kepada Krisna OlehOleh Khas Bali adalah memperbaiki kinerja yang dianggap kurang seperti prioritas yang sudah disebutkan.
\end{abstract}

Keywords: krisna oleh-oleh khas bali, satisfaction. 


\section{PENDAHULUAN}

Pariwisata adalah perjalanan dari suatu tempat ke tempat lain, bersifat sementara, dilakukan perorangan atau kelompok, sebagai usaha mencari keseimbangan atau keserasian dan kebahagiaan dengan lingkungan dalam dimensi sosial, budaya, alam dan ilmu (Kodhyat,1998). Pariwisata, khususnya di Bali terus mengalami peningkatan, namun persentase pertumbuhannya mengalami fluktuasi. Penyebab terjadinya fluktuasi pertumbuhan tersebut salah satunya dikarenakan pada tahun 2015 terjadi krisis di Kawasan Uni Eropa sehingga kunjungan wisatawan dari Eropa menurun drastis. Kunjungan wisatawan Nusantara ke Bali berdasarkan tabel diatas, dalam 5 tahun terakhir, jumlah kunjungan dan persentase pertumbuhan wisatawan nusantara ke Bali juga mengalami fluktuasi namun jumlah kunjungan wisatawan nusantara ke Bali terus meningkat sejak mengalami penurunan di tahun 2014 dan ada beberapa hal yang menarik wisatawan nusantara saat mengunjungi Bali yaitu daya tarik alam dan daya tarik budaya namun tidak hanya dua hal tersebut yang menarik minat wisatawan nusantara saat berkunjung ke Bali, ada satu hal yang menarik minat mereka yaitu daya tarik buatan seperti salah satunya adalah pusat perbelanjaan.

Pusat perbelanjaan memiliki presentase tertinggi kedua setelah fasilitas rekreasi liburan yaitu sebesar 21,6\% dan fasilitas rekreasi liburan memiliki presentase sebesar $52,2 \%$. Sedangkan fasilitas perisirahatan 8,6 $\%$, monumen $5,3 \%$, fasilitas rekrasi olahraga $4,9 \%$, lainnya $4,6 \%$ dan barang kerjinan sebesar 2,5\%. Dari data diatas, dapat diketahui banyak dari wisatawan nusantara yang berbelanja saat berlibur di Bali. Kini pusat perbelanjaan yaitu pusat oleh-oleh di Bali sudah beraneka ragam dan tersebar dimanamana, mulai dari pusat oleh-oleh tradisional maupun pusat oleh-oleh modern. Hal itu dikarenakan kegiatan berbelanja (shopping merupakan jenis kegiatan atau atraksi wisata yang paling diminati wisatawan nusantara saat berkunjung ke Bali setelah sight-seeing (melihat-lihat).

Shopping (berbelanja) menempati urutan kedua terbanyak dengan persentase sebesar $43,5 \%$ setelah sight-seeing (melihatlihat) dengan persentase $50,5 \%$. Selain karena shopping (berbelanja) menjadi kegiatan yang paling banyak dilakukan wisatawan nusantara di Bali setelah Sight-seeing (melihat-lihat), alokasi pengeluaran wisatawan nusantara untuk pembelian souvenir juga menempati tempat kedua terbanyak. Shopping menjadi atraksi wisata kedua yang paling diminati wisatawan nusantara saat berkunjung ke Bali dan wisatawan mengalokasikan dana yang dimiliki untuk berbelanja souvenir. Souvenir menjadi suatu hal yang sangat penting, jika dilihat dari Bali sebagai tujuan wisata, berjualan souvenir merupakan peluang bisnis yang sangat menjanjikan jika dilihat dari minat dan pengalokasian dana wisatawan nusantara terhadap souvenir dari data-data yang tersedia diatas. Dengan demikian kondisi ekonomi masyarakat lokal bisa meningkat dengan berjualan souvenir.

Krisna oleh-oleh Khas Bali yang dipilih adalah di Kawasan Bali Selatan yang meliputi Krisna Oleh-Oleh Khas Bali di Jl.Sunset Road 88 Kuta, Jl.Raya Tuban No.2X Kuta, dan Jl. Nusa Kambangan No. 160 A untuk dilakukan pengukuran mengenai kepuasan berbelanja wisatawan nusantara di Krisna Oleh-Oleh Khas Bali Kawasan Bali Selatan. Dengan alasan, ketiga Krisna tersebut sesuai dengan indikator yang digunakan untuk mengukur kepuasan yaitu in-store dan out-store yang diadaptasi dari Atila Yuksel (2005) yang mengatakan bahwa tourist shopping behavior berpengaruh terhadap emotions, shopping value dan behaviours oleh karena itu in-store dan out-store perlu diberi perhatian khusus agar wisatawan puas. Ditambahkan juga faktor marketing mix untuk memperlengkapi faktor in-store dan out-store untuk menentukan kepuasan. Alasan lain dipilihnya Krisna OlehOleh karena Krisna Oleh-Oleh Khas Bali adalah pusat oleh-oleh yang paling banyak memiliki cabang di Bali terutama di Kawasan Bali Selatan dengan jumah 6 cabang. Selain itu, alasan dilakukannya pengukuran tingkat kepuasan berbelanja wisatawan nusantara di Krisna Oleh-Oleh Khas Bali karena berdasarkan data yang didapatkan dari komentar di trip advisor ada beberapa point kekurangan yang di komentari oleh wisatawan yang sebelumnya berbelanja di Krisna OlehOleh. Kepuasan wisatawan saat berbelanja sangat penting, oleh karena perlu diketahui tingkat kinerja, tingkat harapan dan analisis tingkat kepuasan berbelanja menggunakan faktor in-store, out-store dan marketing mix dalam menentukan bagaimanakah kepuasan berbelanja wisatawan nusantara di Krisna Oleh 
-Oleh Khas Bali agar hasil yang didapat ini bisa meningkatkan pelayanan Krisna OlehOleh Khas Bali.

\section{METODE}

Tiga cabang Krisna Oleh-Oleh Khas Bali yang dipih berada di Bali Selatan yaitu Krisna Oleh-Oleh Khas Bali Jl. Sunset Road 88 Kuta, Rama Krisna Jalan Raya Tuban No.2X Kuta, dan Krisna Oleh-Oleh Khas Bali Jalan Nusakambangan No.160A. Ketiga cabang Krisna Oleh-Oleh Khas Bali tersebut dapat ditempuh dari Bandar Udara Internasional Ngurah Rai dengan waktu 5-25 menit, jika tujuannya Krisna Oleh-Oleh Khas Bali Jalan Raya Tuban dan Jalan Sunset Road. Sedangkan menuju Krisna Oleh-Oleh Khas Bali Jalan Nusakambangan menghabiskan waktu 30-45 menit.

Pengukuran dilakukan menggunakan 3 faktor, faktor yang pertama adalah in-store dengan indikator desain interior, musik dan aroma. Faktor kedua adalah out-store dengan indikator arsitektur atau bentuk bangunan, fasilitas tambahan (ATM), lahan parkir, toilet, food court, area tunggu, tingkat kepadatan dan tingkat kebisingan. Faktor ketiga adalah marketing mix dengan indikator lokasi, pelayanan, communication action (pengiklanan dan promosi), tatanan didalam toko, harga, dan produk.

Teknik pengumpulan data yang digunakan adalah observasi, kuesioner, dokumentasi dan studi kepustakaan. Teknik penentuan sampel menggunakan rumus Lemeshow populasi tidak diketahui, sehingga didapatkan hasil sebesar 100 sampel.

Teknik analisis data ini menggunakan 4 tahap, yang pertama teknik analisis deskriptif kuantitatif dengan menjabarkan data angka yang diperoleh dengan menguraikan secara terperinci. Yang kedua menggunakan uji validitas dan reliabilitas untuk menentukan apakah hasil kuesioner itu valid dan reliabel untuk dilanjutkan ke tahap selanjutnya. Yang ketiga, tingkat kesesuaian yang digunakan untuk perbandingan antara skor tingkat kepentingan dan tingkat kinerja. Tingkat kesesuaian inilah yang akan menentukan urutan prioritas faktor-faktor yang mempengaruhi kepuasan wisatawan setelah dijabarkan dalam diagram kartesius untuk mengetahui indikator-indikator kualitas pelayanan terhadap wisatawan yang memuaskan dan tidak memuaskan. Menurut
Supranto (2011) dalam Ni Komang Ayu Trisna Dewi, 2018 terdapat dua hal yang dapat terjadi dalam tingkat kesesuaian, yaitu:

1. Apabila kinerja atau kepuasan berada dibawah kepentingan atau ekspektasi, maka wisatawan akan merasa tidak puas dan kecewa, dengan perincian nilai sebagai berikut.
a. $0 \%-32 \%$ wisatawan sangat tidak puas
b. $33 \%-65 \%$ wisatawan tidak puas
c. $66 \%-99 \%$ wisatawan kurang puas

2. Apabila kinerja atau kepuasan sesuai dengan kepentingan atau ekspektasi, maka wisatawan akan puas. Sedangkan bila kinerja melebihi kepentingan maka wisatawan akan sangat puas, dengan perincian sebagai berikut.

a. tingkat kesesuaian $100 \%$ maka wisatawan puas

b. tingkat kesesuaian > 100\% maka wisatawan merasa sangat puas.

Yang keempat adalah Importace Performance Analysis (IPA), analisis ini digunakan untuk mengetahui sejauh mana tingkat kepentingan kinerja terhadap kepuasan.

\section{HASIL DAN PEMBAHASAN Hasil}

Krisna Oleh-Oleh Khas Bali merupakan pusat perbelanjaan oleh-oleh modern yang memiliki gaya dan nuansa budaya khas Bali. Krisna Oleh-Oleh Khas Bali didirikan oleh seorang pria asal Buleleng yang bernama Gusti Ngurah Anom. Sebelum sebelum Krisna Oleh-Oleh Khas Bali ini berdiri Gusti Ngurah Anom membuka usaha konfeksinya yang dengan nama Cok Konfeksi yang berlokasi di Jalan Nusa Indah Denpasar. Dengan hak penuh kepemilikan, Cok Konfeksi semakin tajam membangun jaringan kerja dan telah mampu diperhitungkan sebagai salah satu industri besar di Bali. Gusti Ngurah Anom memiliki ketekunan, kesabaran dan kejelian dalam membaca peluang yang didasari kreativitas dan inovasi. Kemudian Gusti Ngurah Anom menggagas sebuah ekspansi usaha seperti sentral oleh-oleh khas Bali yang menjual aneka camilan, kaos, tas kreasi, alat music tradisional, aksesoris, bedcover, lukisan, kerajinan kayu, alas kaki hingga frame foto untuk memanfaatkan arus wisatawan yang berkunjung di Bali.

Ide itupun kemudian berhasil terealisasi dengan dibukanya sebuah pusat oleh-oleh Bali 
yang bernama Krisna Oleh-Oleh Khas Bali pada tanggal 16 Mei 2007 di Jalan Nusa Indah No.77 Denpasar. Kemudian terpikir oleh Gusti Ngurah Anom untuk memulai produksi baju kaos sendiri sebagai oleh-oleh khas Bali bergambar karikatur, dan benar saja kaos tersebut meledak diminati pasar. Setelah Krisna Oleh-Oleh Khas Bali ini sukses dan diminati wisatawan, Gusti Ngurah Anom menggandeng pemilik properti di Kawasan Jalan Nusa Kambangan Denpasar untuk bekerjasama mendirikan Krisna Oleh-Oleh Khas Bali yang kedua yang dirancang matang dengan areal parkir yang luas, sarana belanja yang lapang serta berbagai fasilitas kenyamanan berbelanja. Dan secara resmi Krisna Oleh-Oleh Khas Bali yang kedua di Jalan Nusa Kambangan 160 A Denpasar resmi dibuka pada tanggal 16 Mei 2008.

Dalam waktu yang relatif singkat, Krisna Oleh-Oleh Khas Bali cepat popular. Jaringan kerjasama yang dibangun Gusti Ngurah Anom dengan praktisi pariwisata dan komponen pendukungnya seperti biro perjalanan, Himpunan Pramuwisata Indonesia (HPI) dan juga para pengemudi jasa angkutan wisata, taxi dan sebagainya dirasa sebagai terobosan jitu semakin mentenarkan nama Krisna Oleh-Oleh Khas Bali sebagai pusat belanja oleh-oleh Khas Bali dengan harga murah dan bermutu. Keberhasilan Oleh-Oleh Khas Bali Nusakambangan kembali memacu gairah wirausaha Gusti Ngurah Anom untuk mempersembahkan sebuah mega areal pusat belanja oleh-oleh terbesar di Bali. Tepat tanggal 16 Mei 2009 resmi dibuka pusat perbelanjaan Krisna Oleh-Oleh Khas Bali di Kawasan Sunset Road Kuta, yang sengaja dibangun untuk memudahkan dan memanjakan para wisatawan untuk berbelanja oleh-oleh Khas Bali dengan nyaman dan hemat.

Terinspirasi dari kehidupan dikawasan Kuta yang tak pernah padam, muncul ide untuk mendirikan Krisna Oleh -Oleh Khas Bali yang mengikuti kehidupan dikawasan Kuta yang tidak pernah padam, akhirnya pada tanggal 1 November 2010 resmi dibuka Krisna Oleh-Oleh Khas Bali yang keempat dengan nama Rama Krisna Oleh-Oleh Khas Bali dengan konsep buka 24 jam nonstop.

Berdasarkan hasil penyebaran kuesioner, karakteristik wisatawan nusantara yang berbelanja di Krisna Oleh-Oleh Khas Bali diperoleh bahwa mayoritas wisatawan nusantara berasal dari Surabaya dengan persentase sebesar 33\%. Jenis kelamin paling banyak berbelanja di Krisna Oleh-Oleh Khas Bali adalah perempuan dengan persentase sebesar 66\% Karakteristik berdasarkan pekerjaan yang mendominasi adalah mahasiswa dengan persentase $43 \%$ Karateristik berdasarkan lama kunjungan adalah 1 jam dengan persentase sebesar $40 \%$.

Dari hasil uji validitas, instrumen tersebut dikatakan valid apabila koefisiennya sama dengan atau melebihi 0,361 (df=n-2, dengan sig 5\%). dari 17 indikator dengan 26 sub indikator yang diuji, diketahui keseluruhan indikator dinyatakan valid dikarena koefisiennya sama dengan atau melebihi 0,361 yang artinya memiliki hubungan Kepuasan Berbelanja Wisatawan Nusantara yang berbelanja di Krisna Oleh-Oleh Khas Bali. Uji reliabilitas ini menggunakan ukuran sampel sebanyak 30 responden menunjukkan bahwa angka dari nilai alpha Cronbach's sebesar 0,926 yang berarti nilai tersebut telah memenuhi syarat atau reliable $>0,6$. Hal ini menunjukkan bahwa kuesioner yang telah diuji dapat memberikan hasil yang konsisten bila nantinya dilakukan pengujian atau pengukuran kembali.

Tingkat harapan merupakan suatu harapan dari wisatawan terhadap kinerja dari Krisna Oleh-Oleh Khas Bali. Tingkat harapan didapatkan dari penyebaran kuesioner kepada wisatawan nusantara yang berbelanja di Krisna Oleh-Oleh Khas Bali. Faktor in-store dengan indikator desain interior yang digunakan didalam gedung memperoleh nilai rata-rata harapan sebesar 4,41 yang berarti indikator tersebut dianggap sangat penting guna menunjang kepuasan berbelanja di Krisna Oleh-Oleh Khas Bali. Selanjutnya indikator variasi musik yang dimainkan dapat menambah gairah berbelanja memperoleh nilai rata-rata harapan sebesar 3,22 yang berarti indikator tersebut cukup penting bagi wisatawan yng berbelanja di Krisna OlehOleh Khas Bali. Indikator selanjutnya adalah aroma didalam toko memperoleh nilai ratarata harapan sebesar 4,33 yang artinya hal tersebut dianggap sangat penting bagi wisatawan yang berbelanja di Krisna OlehOleh Khas Bali. Dan yang selanjutnya adalah staf yang bertugas memiliki bau atau aroma yang tidak menyengat memperoleh nilai rata- 
rata harapan sebesar 4,09 yang berarti indikator tersebut dianggap penting oleh wisatawan yang berbelanja di Krisna OlehOleh Khas Bali. Jadi nilai rata-rata harapan untuk faktor in-store sebesar 4,01 dengan kategori penting.

Dari faktor out-store, indikator desain atau bentuk bangunan yang memperoleh nilai rata-rata harapan sebesar 3,91 yang artinya indikator tersebut dianggap penting oleh wisatawan yang berbelanja di Krisna OlehOleh Khas Bali. Selanjutnya adalah indikator fasilitas tambahan (ATM) memperoleh nilai rata-rata harapan sebesar 4,09 yang artinya indikator tersebut dianggap penting oleh wisatawan yang berbelanja di Krisna OlehOleh Khas Bali. Indikator berikutnya adalah keamanan di area parkir memperoleh nilai rata-rata harapan sebesar 4,07 yang artinya indikator tersebut dianggap penting guna memuaskan wisatawan yang berbelanja di Krisna Oleh-Oleh Khas Bali. Indikator ketersediaan lahan parkir yang luas memperoleh nilai rata-rata harapan sebesar 4,01 yang artinya indikator tersebut dianggap penting oleh wisatawan yang berbelanja di Krisna Oleh-Oleh Khas Bali. Berikutnya adalah indikator toilet yang disediakan sangat terjaga kebersihannya memperoleh nilai ratarata harapan sebesar 4,13 yang artinya indikator tersebut dianggap penting oleh wisatawan yang berbelanja di Krisna OlehOleh Khas Bali. Indikator selanjutnya adalah kebersihan dan kenyamanan di area food court masing-masing memperoleh nilai rata-rata harapan sebesar 4,20 dan 4,28 yang artinya indikator kebersihan area food court tersebut dianggap penting sedangkan indikator kenyamanan di area food court dianggap sangat penting oleh wisatawan yang berbelanja di Krisna Oleh-Oleh Khas Bali. Indikator variasi makanan yang dijual di area food court memperoleh nilai rata-rata harapan sebesar 4,13 yang artinya indikator tersebut dianggap penting oleh wisatawan yang berbelanja di Krisna Oleh-Oleh Khas Bali guna meningkatkan kepuasan berbelanja. Indikator berikutnya adalah kenyamanan area tunggu memperoleh nilai raata-rata harapan sebesar 4,32 yang artinya indikator tersebut sangat penting keberadaannya. Kemudian indikator kepadatan pengunjung di area toko tidak mengganggu kenyamanan memperoleh nilai rata-rata harapan sebesar 4,34 yang artinya indikator tersebut dianggap penting oleh wisatawan yang berbelanja di Krisna OlehOleh Khas Bali. Indikator terakhir pada faktor out-store adalah tingkat kebisingan diluar dan area toko memperoleh nilai rata-rata harapan sebesar 4,24 yang artinya indikator tersebut dianggap penting oleh wisatawan yang berbelanja di Krisna Oleh-Oleh Khas Bali. Jadi nilai rata-rata harapan faktor out-store adalah sebesar 4,15 dengan kategori penting.

Faktor yang terakhir yaitu faktor marketing mix memiliki indikator sebagai berikut, indikator Krisna Oleh-Oleh Khas Bali mudah dicapai dan strategis memperoleh nilai rata-rata harapan sebesar 4,15 yang artinya indikator tersebut dianggap penting oleh wisatawan yang berbelanja di Krisna OlehOleh Khas Bali. Berikutnya adalah indikator staf yang bertugas ramah terhadap pengunjung memperoleh nilai rata-rata harapan sebesar 4,15 yang artinya indikator tersebut dianggap penting oleh wisatawan agar wisatawan yang berbelanja di Krisna Oleh-Oleh Khas Bali merasa nyaman dan puas. Indikator staf yang bertugas memiliki pengetahuan mengenai produk dan lingkungan berbelanja memperoleh nilai rata-rata harapan sebesar 4,00 yang artinya indikator tersebut dianggap penting oleh wisatawan yang berbelanja di Krisna Oleh-Oleh Khas Bali. Berikutnya adalah indikator penawaran special atau diskon memperoleh nilai rata-rata harapan sebesar 4,21 yang artinya indikator tersebut dianggap penting dan diinginkan oleh wisatawan yang berbelanja di Krisna OlehOleh Khas Bali. Indikator iklan mengenai toko memperoleh nilai rata-rata harapan sebesar 3,90 yang berarti hal tersebut diangap penting oleh wisatawan, kemudian indikator pengklasifikasian tatanan produk didalam toko mendapat nilai 3,83 yang artinya hal tersebut dianggap penting keberadaannya oleh wisatawan. Selanjutnya adalah kerapihan dalam toko memperoleh nilai sebesar 4,38 yang artinya hal tersebut dianggap sangat penting oleh wisatawan, kemudian indikator harga yang ditawarkan juga dianggap sangat penting oleh wisatawan karena memperoleh nilai sebesar 4,36. Pengemasan atau packing barang yang sudah dibeli pun masuk ke dalam kategori sangat penting karena memperoleh nilai 4,29. Variasi dan kualitas produk yang dijual pun masuk ke dalam kategori sangat penting dengan perolehan nilai masing-masing 4,28 dan 4,37. Jadi nilai rata-rata harapan faktor marketing mix sebesar 4,17 dengan 
kategori penting. Nilai rata-rata harapan keseluruhan memperoleh nilai 4,14 dengan kategori kinerjanya penting.

Tingkat kinerja merupakan suatu kinerja atau pelayanan yang diberikan oleh Krisna Oleh-Oleh Khas Bali kepada wisatawan nusantara yang berbelanja di Krisna OlehOleh Khas Bali. dari faktor in-store dengan indikator desain interior yang digunakan didalam gedung memperoleh nilai rata-rata kinerja 3,86 yang berarti indikator tersebut kinerjanya sudah baik guna menunjang kepuasan berbelanja di Krisna Oleh-Oleh Khas Bali. Selanjutnya indikator variasi musik yang dimainkan dapat menambah gairah berbelanja memperoleh nilai rata-rata kinerja sebesar 3,86 yang berarti indikator tersebut kinerjanya sudah baik. Indikator selanjutnya adalah aroma didalam toko memperoleh nilai rata-rata kinerja sebesar 3,74 yang artinya hal tersebut kinerjanya sudah baik. Dan yang selanjutnya adalah staf yang bertugas memiliki bau atau aroma yang tidak menyengat memperoleh nilai rata-rata kinerja sebesar 3,57 yang berarti indikator tersebut kinerjanya sudah baik. Jadi nilai rata-rata kinerja untuk faktor in-store sebesar 3,75 dengan kategori baik.

Dari faktor out-store, indikator desain atau bentuk bangunan yang memperoleh nilai rata-rata kinerja sebesar 4,05 yang artinya indikator tersebut kinerjanya sudah baik. Selanjutnya adalah indikator fasilitas tambahan (ATM) memperoleh nilai rata-rata kinerja sebesar 3,94 yang artinya indikator tersebut kinerjanya sudah baik guna meningkatkan kepuasan berbelaja wisatawan. Indikator berikutnya adalah keamanan di area parkir memperoleh nilai rata-rata kinerja sebesar 4,01 yang artinya indikator tersebut sudah dilakukan dengan baik oleh pihak Krisna Oleh-Oleh Khas Bali. Indikator ketersediaan lahan parkir yang luas memperoleh nilai rata-rata kinerja sebesar 3,94 yang artinya indikator tersebut kinerjnya sudah baik. Berikutnya adalah indikator toilet yang disediakan sangat terjaga kebersihannya memperoleh nilai rata-rata kinerja sebesar 3,68 yang artinya indikator tersebut sudah dijalankan dengan baik. Indikator selanjutnya adalah kebersihan dan kenyamanan di area food court masing- masing memperoleh nilai rata-rata kinerja sebesar 3,58 dan 3,54 yang artinya indikator kebersihan area food court dan kenyamanan di area food court kinerjanya dianggap sudah baik oleh wisatawan. Indikator variasi makanan yang dijual di area food court memperoleh nilai rata-rata kinerja sebesar 3,61 yang artinya indikator tersebut kinerjanya sudah baik. Indikator berikutnya adalah kenyamanan area tunggu memperoleh nilai rata-rata kinerja sebesar 3,67 yang artinya kinerja untuk indikator tersebut sudah baik. Kemudian indikator kepadatan pengunjung di area toko tidak mengganggu kenyamanan memperoleh nilai rata-rata kinerja sebesar 3,96 yang artinya indikator tersebut kinerjanya sudah baik. Indikator terakhir pada faktor outstore adalah tingkat kebisingan diluar dan area toko memperoleh nilai rata-rata kinerja sebesar 3,68 yang artinya indikator tersebut kinerjanya sudah baik. Jadi nilai rata-rata kinerja faktor out-store adalah sebesar 3,78 dengan kategori baik.

Dari faktor yang terakhir yaitu faktor marketing mix memiliki indikator sebagai berikut, indikator Krisna Oleh-Oleh Khas Bali mudah dicapai dan strategis memperoleh nilai rata-rata kinerja sebesar 4,01 dengan kategori kinerja baik. Berikutnya adalah indikator staf yang bertugas ramah terhadap pengunjung memperoleh nilai rata-rata kinerja sebesar 4,00 dengan kategori kinerja baik. Indikator staf yang bertugas memiliki pengetahuan mengenai produk dan lingkungan berbelanja memperoleh nilai rata-rata kinerja sebesar 3,92 dengan kategori kinerja baik.Berikutnya adalah indikator penawaran special atau diskon memperoleh nilai rata-rata kinerja sebesar 3,18 dengan kategori kinerja cukup baik. Indikator iklan mengenai toko memperoleh nilai rata-rata harapan sebesar 3,38 dengan kategori kinerja cukup baik, kemudian indikator pengklasifikasian tatanan produk didalam toko mendapat nilai 4,06 dengan kategori kinerja baik. Selanjutnya adalah kerapihan dalam toko memperoleh nilai sebesar 4,04 yang artinya hal tersebut kinerjanya sudah baik, kemudian indikator harga yang ditawarkan juga kinerjanya baik karena memperoleh nilai sebesar 3,80. Pengemasan atau packing barang yang sudah dibeli pun masuk ke dalam kategori baik karena memperoleh nilai 4,02. Variasi dan kualitas produk yang dijual pun masingmasing memperoleh nilai 4,25 dengan kategori sangat baik dan 3,96 dengan kategori baik. Jadi nilai rata-rata kinerja faktor marketing mix 3,87 dengan kategori kinerja baik. Nilai 
rata-rata kinerja keseluruhan memperoleh nilai 3,8 dengan kategori kinerjanya baik.

Tingkat kepuasan dapat diketahui dengan cara menganalisis hubungan antara harapan dan kinerja Krisna Oleh-Oleh Khas Bali terhadap tingkat kepuasan wisatawan nusantara, dari analisis tingkat kepuasan berbelanja wisatawan nusantara di Krisna Oleh-Oleh Khas Bali didapatkan hasil sebagai berikut. Dari faktor in-store sub indikator pertama, desain interior yang digunakan didalam gedung menarik memperoleh skor tingkat kinerja sebesar 386, sedangkan skor tingkat kepentingan sebesar 441. Dari skor tingkat kinerja dan tingkat kepentingan tersebut didapatkan skor tingkat kesesuaian sebesar $87,5 \%$. Hal ini menunjukkan bahwa wisatawan merasa kurang puas dengan kinerja dari Krisna Oleh-Oleh Khas Bali. Sub indikator kedua, variasi musik yang dimainkan dapat menambah gairah berbelanja memperoleh skor tingkat kinerja sebesar 386, sedangkan skor tingkat kepentingan sebesar 322. Dari skor tingkat kinerja dan tingkat kepentingan tersebut didapatkan skor tingkat kesesuaian sebesar 119,8 \%. Hal ini menunjukkan bahwa wisatawan merasa sangat puas dengan kinerja dari Krisna Oleh-Oleh Khas Bali. Sub indikator ketiga, aroma didalam toko sangat harum memperoleh skor tingkat kinerja sebesar 374, sedangkan skor tingkat kepentingan sebesar 433. Dari skor tingkat kinerja dan tingkat kepentingan tersebut didapatkan skor tingkat kesesuaian sebesar 86,3\%. Hal ini menunjukkan bahwa wisatawan merasa kurang puas dengan kinerja dari Krisna Oleh-Oleh Khas Bali dalam hal membuat aroma dalam toko yang harum. Sub indikator keempat, staf yang bertugas memiliki aroma atau bau yang tidak menyengat memperoleh skor tingkat kinerja sebesar 357, sedangkan skor tingkat kepentingan sebesar 409. Dari skor tingkat kinerja dan tingkat kepentingan tersebut didapatkan skor tingkat kesesuaian sebesar $87,2 \%$. Hal ini menunjukkan bahwa wisatawan merasa kurang puas dengan kinerja Krisna Oleh-Oleh Khas Bali pada indikator ini.

Dari faktor out-store, sub indikator pertama desain atau bentuk bangunan yang menarik memperoleh skor tingkat kinerja sebesar 405, sedangkan skor tingkat kepentingan sebesar 391. Dari skor tingkat kinerja dan tingkat kepentingan tersebut didapatkan skor tingkat kesesuaian sebesar $103,5 \%$. Hal ini menunjukkan bahwa wisatawan merasa sangat puas dengan kinerja Krisna Oleh-Oleh Khas Bali pada indikator ini. Sub indikator fasilitas tambahan (ATM) lengkap memperoleh skor tingkat kinerja sebesar 394, sedangkan skor tingkat kepentingan sebesar 409. Dari skor tingkat kinerja dan tingkat kepentingan tersebut didapatkan skor tingkat kesesuaian sebesar 96,3 \%. Hal ini menunjukkan bahwa wisatawan merasa kurang puas dengan kinerja Krisna Oleh-Oleh Khas Bali pada indikator ini. Indikator keamanan di area parkir sangat aman memperoleh skor tingkat kinerja sebesar 401, sedangkan skor tingkat kepentingan sebesar 407. Dari skor tingkat kinerja dan tingkat kepentingan tersebut didapatkan skor tingkat kesesuaian sebesar 98,5 \%. Hal ini menunjukkan bahwa wisatawan merasa kurang puas dengan kinerja Krisna Oleh-Oleh Khas Bali pada indikator ini dan didukung dari hasil observasi dimana hanya ada satu tukang parkir yang berjaga di area parkir dan sebagian besar security berada di area dalam toko. Sub indikator ketersediaan lahan parkir yang luas memperoleh skor tingkat kinerja sebesar 394, sedangkan skor tingkat kepentingan sebesar 401. Dari skor tingkat kinerja dan tingkat kepentingan tersebut didapatkan skor tingkat kesesuaian sebesar 98,2 \%. Hal ini menunjukkan bahwa wisatawan merasa kurang puas dengan kinerja Krisna Oleh-Oleh Khas Bali pada indikator ini. Sub indikator toilet yang disediakan sangat terjaga kebersihannya memperoleh skor tingkat kinerja sebesar 368, sedangkan skor tingkat kepentingan sebesar 413. Dari skor tingkat kinerja dan tingkat kepentingan tersebut didapatkan skor tingkat kesesuaian sebesar $89,1 \%$. Hal ini menunjukkan bahwa wisatawan merasa kurang puas dengan kinerja Krisna Oleh-Oleh Khas Bali pada indikator ini dan hal tersebut dapat didukung dengan hasil observasi di Krisna Oleh-Oleh Khas Bali dimana toilet yang disediakan sudah cukup bersih namun sebagian besar peralatan di toilet yang agak menghitam dan cermin yang kurang bersih. Sub indikator kebersihan area food court sangat terjaga memperoleh skor tingkat kinerja sebesar 358, sedangkan skor tingkat kepentingan sebesar 420. Dari skor tingkat kinerja dan tingkat kepentingan tersebut didapatkan skor tingkat kesesuaian sebesar $85,2 \%$. Hal ini menunjukkan bahwa 
wisatawan merasa kurang puas dengan kinerja Krisna Oleh-Oleh Khas Bali pada indikator ini dan didukung dari hasil observasi dimana lantai kurang bersih dikarenakan banyaknya wisatawan yang berlalu-lalang disana. Sub indikator kenyamanan do area food court sangat baik memperoleh skor tingkat kinerja sebesar 354, sedangkan skor tingkat kepentingan sebesar 428. Dari skor tingkat kinerja dan tingkat kepentingan tersebut didapatkan skor tingkat kesesuaian sebesar $82,7 \%$. Hal ini menunjukkan bahwa wisatawan merasa kurang puas dengan kinerja Krisna Oleh-Oleh Khas Bali pada indikator ini dan dapat didukung dengan hasil observasi di lokasi dimana Krisna Oleh-Oleh Khas Bali berada di sebelah jalan utama atau jalan raya jadi tingkat kebisingan cukup tinggi.

Dari faktor marketing mix, Indikator Krisna Oleh-Oleh Khas Bali mudah dicapai dan strategis memperoleh skor tingkat kinerja sebesar 401, sedangkan skor tingkat kepentingan sebesar 415. Dari skor tingkat kinerja dan tingkat kepentingan tersebut didapatkan skor tingkat kesesuaian sebesar 96,6 \%. Indikator staf yang bertugas ramah terhadap pengunjung memperoleh skor tingkat kinerja sebesar 400, sedangkan skor tingkat kepentingan sebesar 415. Dari skor tingkat kinerja dan tingkat kepentingan tersebut didapatkan skor tingkat kesesuaian sebesar $96,3 \%$. Indikator staf yang bertugas memiliki pengetahuan mengenai produk dan lingkungan berbelanja memperoleh skor tingkat kinerja sebesar 392, sedangkan skor tingkat kepentingan sebesar 400. Dari skor tingkat kinerja dan tingkat kepentingan tersebut didapatkan skor tingkat kesesuaian sebesar 98 $\%$. Hal ini menunjukkan bahwa wisatawan merasa kurang puas dengan kinerja Krisna Oleh-Oleh Khas Bali pada indikator ini. Indikator sering diadakannya penawaran spesial atau diskon memperoleh skor tingkat kinerja sebesar 318, sedangkan skor tingkat kepentingan sebesar 421. Dari skor tingkat kinerja dan tingkat kepentingan tersebut didapatkan skor tingkat kesesuaian sebesar $75,5 \%$. Hal ini menunjukkan bahwa wisatawan merasa kurang puas dengan kinerja Krisna Oleh-Oleh Khas Bali pada indikator ini dan didukung dari hasil observasi dilapangan dimana Krisna Oleh-Oleh memang jarang atau hamper tidak pernah mengadakan diskon atau penawaran spesial.
Indikator iklan mengenai toko yang menarik memperoleh skor tingkat kinerja sebesar 338, sedangkan skor tingkat kepentingan sebesar 390. Dari skor tingkat kinerja dan tingkat kepentingan tersebut didapatkan skor tingkat kesesuaian sebesar $86,6 \%$. Hal ini menunjukkan bahwa wisatawan merasa kurang puas dengan kinerja Krisna Oleh-Oleh Khas Bali pada indikator ini dan didukung dari hasil observasi dimana Krisna Oleh-Oleh Khas Bali jarang membuat iklan karena Krisna Oleh-Oleh Khas Bali langsung berhubungan dengan perusahaan dibidang pariwisata untuk mendatangkan tamu. Indikator pengklastifikasian tatanan produk didalam toko sudah baik memperoleh skor tingkat kinerja sebesar 406, sedangkan skor tingkat kepentingan sebesar 383. Dari skor tingkat kinerja dan tingkat kepentingan tersebut didapatkan skor tingkat kesesuaian sebesar $106 \%$. Indikator kerapihan didalam toko sudah baik memperoleh skor tingkat kinerja sebesar 404, sedangkan skor tingkat kepentingan sebesar 438. Dari skor tingkat kinerja dan tingkat kepentingan tersebut didapatkan skor tingkat kesesuaian sebesar $92,2 \%$. Hal ini menunjukkan bahwa wisatawan merasa kurang puas dengan kinerja Krisna Oleh-Oleh Khas Bali.

Indikator harga yang ditawarkan sangat terjangkau memperoleh skor tingkat kinerja sebesar 380, sedangkan skor tingkat kepentingan sebesar 436. Dari skor tingkat kinerja dan tingkat kepentingan tersebut didapatkan skor tingkat kesesuaian sebesar $87,1 \%$. Hal ini menunjukkan bahwa wisatawan merasa kurang puas dengan kinerja Krisna Oleh-Oleh Khas Bali pada indikator ini dan didukung dari hasil observasi di lokasi dimana harga dari produk yang dijual bermacam-macam ada yang kualitas premium dengan harga yang mahal dan kualitas biasa. Indikator pengemasan atau packing barang yang sudah dibeli sangat rapi dan menarik memperoleh skor tingkat kinerja sebesar 402, sedangkan skor tingkat kepentingan sebesar 429. Dari skor tingkat kinerja dan tingkat kepentingan tersebut didapatkan skor tingkat kesesuaian sebesar 93,7 \%. Hal ini menunjukkan bahwa wisatawan merasa kurang puas dengan kinerja Krisna Oleh-Oleh Khas Bali pada indikator ini. Indikator variasi produk yang dijual sangat beragam memperoleh skor tingkat kinerja sebesar 425, sedangkan skor tingkat kepentingan sebesar 
428. Dari skor tingkat kinerja dan tingkat kepentingan tersebut didapatkan skor tingkat kesesuaian sebesar 99,2 \%. Indikator kualitas produk yang dijual sangat baik memperoleh skor tingkat kinerja sebesar 396, sedangkan skor tingkat kepentingan sebesar 437. Dari skor tingkat kinerja dan tingkat kepentingan tersebut didapatkan skor tingkat kesesuaian sebesar 90,6 \%. Hal ini menunjukkan bahwa wisatawan merasa kurang puas dengan kinerja Krisna Oleh-Oleh Khas Bali pada indikator ini.

\section{Pembahasan}

Berdasarkan tingkat kesesuaian pada skor tingkat kinerja dan tingkat kepentingan dapat diketahui tingkat kepuasan berbelanja wisatawan Nusantara di Krisna Oleh-Oleh Khas Bali dengan cara menjumlahkan keseluruhan tingkat kesesuaian masing-masing indikator dari hasil kuesioner yang diberikan kepada wisatawan nusantara yang berbelanja di Krisna Oleh-Oleh Khas Bali. Berdasarkan hasil analisis diperoleh tingkat kepuasan berbelanja wisatawan nusantara di Krisna Oleh-Oleh Khas Bali sebesar 92,4 \% sehingga dapat disimpulkan wisatawan nusantara merasa kurang puas berbelanja di Krisna OlehOleh Khas Bali.

Untuk menganalisis tingkat kepuasan makan digunakan Importance Performance Analysis (IPA). Importance Performance Analysis (IPA) ini digunakan untuk mengetahui sejauh mana tingkat kepentingan kinerja terhadap kepuasan. Terdapat 2 variabel dalam pengukuran ini yaitu $\mathrm{X}$ dan $\mathrm{Y}$, $X$ merupakan variable kinerja atau pelayanan yang mempengaruhi kepuasan sedangkan $\mathrm{Y}$ merupakan tingkat kepentingan atau harapan wisatawan nusantara yang berbelanja di Krisna Oleh-Oleh Khas Bali. Derajat kinerja dan kepentinga diukur menggunakan skala likert dengan 5 poin penilaian, agar dapat mengetahui letak faktor-faktor didiagram cartesius maka harus menentukan titik $\mathrm{X}$ dan $\mathrm{Y}$ yang berpotongan membatasi empat bagian dalam diagram cartesius.

Berdasarkan Diagram Kartesius, dapat dilihat bahwa letak dari setiap indikator yang merupakan penilaian harapan tingkat kepuasan berbelanja wisatawan nusantara di Krisna Oleh-Oleh Khas Bali yang dibagi atas 4 kuadran seperti berikut :

\section{Kuadran A}

Pada kuadran A menunjukkan indikator dianggap penting bagi wisatawan nusantara namun kinerja belum memuaskan bagi wisatawan nusantara. Jadi indikator ini perlu diperhatikan oleh pihak Krisna Oleh-Oleh Khas Bali dikarenakan kinerjanya belum memuaskan wisatawan nusantara yang berbelanja.

1. Aroma didalam toko sangat harum (indikator nomor 3), aroma didalam toko dianggap kurang harum oleh wisatawan karena padatnya jumlah pengunjung di dalam toko sehingga aromanya kurang harum.

2. Kebersihan area food court sangat terjaga (indikator nomor 10), kebersihan area food court dianggap kurang bersih oleh wisatawan karena lantai food court yang kurang bersih.

3. Kenyamanan di area food court sangat baik (indikator nomor 11), kenyamanan di area food court dirasa kurang oleh wisatawan karena banyaknya wisatawan lain yang merokok di area food court tersebut sehingga mengganggu kenyamanan wisatawan yang lain.

4. Kenyamanan area tunggu sangat baik (indikator nomor 13), kenyamanan di area tunggu dirasa kurang oleh wisatawan karena banyaknya perokok yang merokok di ruang tunggu.

5. Tingkat kebisingan di luar dan area toko sangat rendah (indikator nomor 15), tingkat kebisingan di luar dan area toko cukup tinggi dikarenakan padatnya wisatawan yang berkunjung dan berbelanja di Krisna Oleh-Oleh Khas Bali.

6. Sering diadakannya penawaran spesial atau diskon (indikator nomor 19), indikator penawaran special atau diskon dianggap kurang oleh wisatawan karena memang Krisna Oleh-Oleh hampir tidak pernah memberikan penawaran special atau diskon untuk produk-produk yang dijual.

7. Harga yang ditawarkan sangat terjangkau (indikator nomor 23), indikator ini dirasa kurang karena hanya beberapa produk memiliki harga yang murah dan untuk produk makanan khas harganya cukup tinggi.

\section{Kuadran B}

Kuadran B menunjukkan indikator yang penting untuk tingkat kepuasan berbelanja 
wisatawan nusantara di Krisna Oleh-Oleh Khas Bali dikarenakan perusahaan sudah memberikan kinerja dengan sangat baik sehingga perlu untuk dipertahankan.

1. Desain interior yang digunakan didalam gedung menarik (indikator nomor 1), desain interior yang digunakan dirasa sudah cukup baik oleh wisatawan karena cat, perabot dan dekorasi yang digunakan cukup bagus dan menarik.

2. Kepadatan pengunjung di area toko tidak mengganggu kenyamanan (indikator nomor 14), indikator ini dirasa sudah berjalan dengan baik karena Krisna OlehOleh Khas Bali memiliki area toko yang luas walaupun pengunjungnya sangat padat, sehingga hal tersebut tidak mengganggu kenyamanan.

3. Krisna Oleh-Oleh Khas Bali mudah dicapai dan strategis (indikator nomor 16), lokasi Krisna Oleh-Oleh Khas Bali sangat mudah dicapai karena berada di tempat strategis dan di pusat kota yaitu di Kuta dan Denpasar.

4. Staf yang bertugas ramah terhadap pengunjung (indikator nomor 17), staf yang bertugas dianggap ramah oleh wisatawan karena setiap wisatawan masuk selalu disambut oleh staf Krisna OlehOleh Khas Bali.

5. Kerapihan dalam toko sudah baik (indikator nomor 22), kerapihan didalam toko dirasa sudah baik karena staf yang bertugas sigap dalam merapikan produkproduk didalam toko.

6. Pengemasan atau packing barang yang sudah dibeli sangat rapi dan menarik (indikator nomor 24), indikator ini dirasa sudah baik oleh wisatawan karena packing barang menarik dengan identitas Krisna Oleh-Oleh Khas Bali.

7. Variasi produk yang dijual sangat beragam (indikator nomor 25), variasi produk yang dijual sangat beragam mulai dari pakaian, makanan khas, lukisan, tas, kerajinan kayu dan masih banyak lagi.

8. Kualitas produk yang dijual sangat baik (indikator nomor 26), kualitas produk yang dijual dirasa sudah baik oleh wisatawan, seperti kualitas pakaian yang cukup bagus dan lembut, makanan khas yang dijual juga berasal dari supplier yang sudah memiliki kualitas baik.

\section{Kuadran C}

Kuadran C menunjukkan indikator yang tidak terlau diharapkan oleh wisatawan dan kinerja perusahaan juga tidak baik. Jadi pihak Krisna Oleh-Oleh Khas Bali tidak perlu terlalu memperhatikan indikator tersebut.

1. Staf yang bertugas memiliki aroma atau bau yang tidak menyengat (indikator nomor 4), indikator ini dirasa kurang baik dan kurang penting oleh wisatawan karena staf yang bertugas terkadang memiliki bau yang kurang harum sehingga mengganggu kenyamanan wisatawan saat berbelanja.

2. Toilet yang disediakan sangat terjaga kebersihannya (indikator nomor 9), indikator ini dirasa kurang baik namun tidak penting juga untuk wisatawan. Toilet di Krisna Oleh-Oleh Khas Bali cenderung basah dan memiliki lantai yang kurang bersih.

3. Variasi makanan yang dijual di area food court menarik (indikator nomor 12), variasi makanan yang dijual dirasa kurang menarik namun hal tersebut juga dianggap tidak penting oleh wisatawan karena yang dijual hanya minuman dingin dan makanan ringan.

4. Iklan mengenai toko yang menarik (indikator nomor 20), indikator ini dirasa kurang namun dianggap kurang penting oleh wisatawan karena memang Krisna Oleh-Oleh hampir tidak pernah memasang iklan karena Krisna Oleh-Oleh Khas Bali langsung bekerjasama dengan biro perjalanan wisata.

\section{Kuadran D}

Kuadran D menunjukkan indikator kurang diharapkan oleh wisatawan nusantara namun pihak Krisna Oleh-Oleh Khas Bali melakukan kinerja dengan sangat baik sehingga dinilai terlalu berlebihan. Adapun indikatornya sebagai berikut,

1. Variasi musik yang dimainkan dapat menambah gairah berbelanja (indikator nomor 2), indikator ini sudah dijalankan dengan baik namu sebenarnya dianggap kurang penting oleh wisatawan. Krisna Oleh-Oleh Khas Bali selalu memainkan musik yang beragam didalam toko untuk menambah nuansa Bali di toko tersebut.

2. Desain atau bentuk bangunan menarik (indikator nomor 5), desain bangunan tidak terlalu diperhatikan atau dianggap penting oleh wisatawan walaupun desain bangunan Krisna Oleh-Oleh Khas Bali 
menarik. Hal ini dikarenakan setiap wisatawan yang datang langsung diantar ke tempat drop off sehingga wisatawan langsung menikmati bagian dalam toko.

3. Fasilitas tambahan (ATM) lengkap (indikator nomor 6), fasilitas tambahan (ATM) sudah disediakan cukup lengkap oleh Krisna Oleh-Oleh Khas Bali, masingmasing Krisna Oleh-Oleh Khas Bali memiliki 2-5 unit ATM. Hal ini dianggap kurang penting oleh wisatawan karena sebagian besar wisatawan sudah siap uang tunai sebelum berbelanja.

4. Keamanan di area / lahan parkir sangat aman (indikator nomor 7), keamanan di area parkir sudah sangat aman namun dianggap kurang penting oleh wisatawan karena sebagian besar wisatawan langsung turun di area drop off sehingga tidak mengetahui bagaimana keamanan di lahan parkir.

5. Ketersediaan lahan parkir yang luas (indikator nomor 8), ketersediaan lahan parkir sudah sangat luas namun dianggap kurang penting oleh wisatawan karena sebagian besar wisatawan langsung diturunkan di area drop off oleh driver sehingga tidak mengetahui bagaimana kondisi lahan parkir tersebut.

6. Staf yang bertugas memiliki pengetahuan mengenai produk dan lingkungan berbelanja (indikator nomor 18), indikator ini dirasa sudah baik kinerjanya namun dianggap kurang penting oleh wisatawan karena sebagian besar wisatawan jarang bertanya mengenai produk kepada staf yang bertugas.

7. Pengklasifikasian tatanan produk di dalam toko sudah baik (indikator nomor 21), indikator ini dirasa sudah baik kinerjanya namun dianggap kurang penting oleh wisatawan. Wisatawan biasanya tidak memperhatikan tananan di dalam toko karena sebagian besar wisatawan domestik hanya memperhatikan atau berpatokan pada harga.

\section{SIMPULAN DAN SARAN Simpulan}

Berdasarkan pembahasan diatas, didapatkan tingkat harapan wisatawan nusantara yang berbelanja di Krisna Oleh-Oleh Khas Bali dengan rata-rata sebesar 4,14 yang masuk pada kategori penting. Itu artinya semua indikator yang digunakan, penting keberadaanya oleh wisatawan. Didapatkan juga tingkat kinerja Krisna Oleh-Oleh Khas Bali terhadap wisatawan nusantara yang berbelanja di Krisna Oleh-Oleh Khas Bali dengan rata-rata sebesar 3,81 yang masuk pada kategori baik.

Dari hasil tingkat harapan dan tingkat kinerja didapatkan tingkat kesesuaian berbelanja wisatawan nusantara di Krisna Oleh-Oleh Khas Bali sebesar 92,4 \% yang masuk dalam kategori kurang puas. Hal ini dikarenakan tingkat harapan wisatawan nusantara yang berbelanja di Krisna Oleh-Oleh Khas Bali lebih besar dari tingkat kinerja Krisna Oleh-Oleh Khas Bali. Wisatawan memiliki ekspektasi yang tinggi saat berbelanja di Krisna Oleh-Oleh Khas Bali namun kinerja yang diberikan Krisna OlehOleh Khas Bali tidak sesuai dengan ekspektasi wisatawan.

\section{Saran}

Indikator-indikator yang sudah mendapat penilaian baik atau sudah memuaskan wisatawan nusantara harus tetap dipertahankan. Berdasarkan kelemahan yang dimiliki Krisna Oleh-Oleh Khas Bali, untuk selanjutnya diharapkan menggunakan fokus yang berbeda, yaitu minat berkunjung kembali wisatawan nusantara yang berbelanja di Krisna Oleh-Oleh Khas Bali.

Krisna Oleh-Oleh Khas Bali harus memperbaiki atau meningkatkan kinerja di indikator yang kinerjanya kurang seperti, aroma didalam toko yang kurang harum sebaiknya ditambahkan pewangi ruangan otomatis yang dapat menyemportkan parfum ruangan tiap beberapa menit atau menggunakan pewangi ruangan tradisional, kebersihan area food court yang kurang terjaga sebaiknya ada cleaning service yang selalu berjaga disetiap sudut, kenyamanan area food court dan area tunggu yang kurang ini dapat ditingkatkan dengan memberikan smoking area karena ketidaknyamanan yang dirasakan dikarenakan banyak pengunjung yang merokok di area tersebut, tingkat kebisingan yang cukup tinggi, kurang adanya diskon atau penawaran spesial, dan harga. 


\section{Kepustakaan}

Abrudan Ioana Nicoleta dan Dan-Cristian Dabija. 2014. "Measuring clients" satisfaction toward shopping centersEmpirical evidences from Rumania". Babes-Bolyai University.

Dinas Pariwisata Pemerintah Provinsi Bali. "Data statistic wisatawan berkunjung ke Bali pada tahun 2011-2016" . (http://www.disparda.baliprov.go.id/ . diakses tanggal 4 Maret 2018).

Dinas Pariwisata Pemerintah Provinsi Bali."Data statistik mengenai alokasi pengeluaran wisatawan nusantara berkunjung ke Bali”. (http://www.disparda.baliprov.go.id/ . diakses tanggal 4 Maret 2018).

Dinas Pariwisata Pemerintah Provinsi Bali. "Data statistic aktivitas yang dilakukan wisatawan nusantara saat berkunjung ke Bali”.(http://www.disparda.baliprov.go.id /. diakses tanggal 4 Maret 2018).

Krisna Bali. www.krisnabali.co.id. "Sejarah Krisna Oleh-Oleh Khas Bali". Diakses tanggal 1 September 2018.

Kusmayadi dan Sugiarto, Endar. 2000. Metodologi Penelitian dalam Bidang Kepariwisataan. Jakarta: PT. Gramedia Pustaka Utama

Supranto, Johanes 2006, Pengukuran Tingkat Kepuasan Pelanggan Untuk Menaikkan Pangsa Pasar. Jakarta : Rineka Cipta

Upadhya Amitabh. 2016. Souvenir Purchase Intentional Or Incidental: A Case Of The United Arab Emirates. Internasional Journal of Exellence in Tourism, Hospitality and Catering, Vol. 7, Issue 1 \& 2.Research Skyline University College.

Wilkins Huge. 2011. Souvenir : What And Why We Buy. Journal Of Travel Research.

Yuksel Atila. 2005. Tourist Shopping Habitat : Effect on emotions, shopping value and behaviours. Tourism Management
Journal .Adnan Menderes University Turkey.

Tendai Mariri dan Chipunza Crispen. 2009.“In store shopping environment and impulsive buying". African Journal of Marketing Management Vol. 1(4) pp. 102-108. University of Fort Hare.

Tjiptono Fandy dan Gregorius Chandra. 2016. Service, Quality dan Satisfaction edisi 4. Yogyakarta. Andi Yogyakarta.

Trisna Dewi Ni Komang Ayu. 2018. "Analisis Kepuasan Wisatawan Pengguna Jasa Transportasi Koperasi Angkutan pariwisata Surya Kencana Sanur". (Laporan Tugas Akhir). Denpasar. Universitas Udayana.

Liputan6.https://www.liputan6.com/bisnis/rea d/2272423/ekonomi-goyah-kunjunganturis-eropa-ke-bali-anjlok. "Ekonomi Goyah, Kunjungan Turis Eropa ke Bali Anjlok". Diakses pada tanggal 19 Oktober 2018.

Westbrook Robert A dan Reilly Michael D. 1983. "Value-Percept Disparity:an Alternative to the Disconfirmation of Expectation Theory of Consumer Satisfaction", Consumer Research Volume 10. 